\title{
5 - Unifying Germany: Crisis, Conflict, and Social Partnership in the East
}

Lowell Turner

What was earlier an open question has now been resolved. Social partnership, including comprehensive collective bargaining, codetermination, influential unions, and employer associations, has been successfully established on new foundations in eastern Germany. This remarkable outcome, and the revolution in social relations that it implies, occurred in an extraordinarily short period of historical time (1990-94).

Far from a foregone conclusion, the development of modern social partnership relations in eastern Germany was very much in doubt in the early years after unification. Intelligent and well-informed observers suggested that a transfer of institutions from the West would not be successful, that employers would take advantage of new labor markets and low wages in the East to undermine the strength of German unions and fundamentally alter the German system of industrial relations, pushing toward a so-called Americanization-namely, deregulation and weakly organized labor (see, for example, Armingeon I99x and Mahnkopf 199I and 1993).

I argue that social partnership is alive and well in eastern Germany. My evidence for this surprising outcome includes the IG Metall strike victory of 1993 and plant-level case studies of restructuring and industrial relations in the metal and electronics industries of eastern Germany. The success of social partnership in eastern Germany can be traced both to the flexible

Funding for this research was provided by the German Marshall Fund of the United States; the Institute of Collective Bargaining, the Institute of European Studies, and the Center for Advanced Human Resource Studies, all three at Cornell University; and the Wissenchaftszentrum in Berlin. Many thanks to Michael Fichter, Charles Heckscher, Richard Locke, and Kathleen Thelen for detailed comments on earlier drafts. 
suitability of institutions transferred from the West and to the actor choices in the negotiations and conflicts that have made it possible to adapt these institutions to a new environment. Both the institutional and political aspects of the argument are necessary to explain the success of social partnership in eastern Germany.

This issue is important not only for what it tells us about the political economy of unified Germany but also for the theoretical and practical lessons we can draw about institutional transfer, adaptation, and reinvigoration. In spite of extraordinary dislocation and hardship among its population, eastern Germany now appears well on the road to economic prosperity and democratic stability. This outcome, however, can be explained neither by the coming of a market economy in itself nor by markets combined with institutional transfer from the former West Germany under the terms of the unification treaty. Markets always require appropriate institutional regulation (Polanyi 1957; Hall 1986); at the same time, it is quite clear that institutions cannot be directly transferred from one area or society to another without being modified to fit local circumstances. New institutions, whether imported or locally developed, must build on the legacies and remnants of existing institutions and practices (Stark 1992). Both the case studies and the strike story presented here demonstrate how the West German institutions of social partnership have built successfully on earlier and existing practices in eastern Germany.

When institutions adapt to new circumstances, both are changed. This mutual process of influence and change, even in the one-sided process of unification, points to a broader conclusion: institutional expansion, transfer, and adaptation to new circumstances leads to institutional change. Such a process of change, although painful, may result in institutional reinvigoration or even reinvention; if it does not, the alternative may well be stagnation and decline.

Institutional expansion and adaptation to new circumstances, although necessary, are also risky. While social partnership is now newly established in eastern Germany, the necessary adaptations (similar to what Stark 1994 calls "recombination") exert pressure for change within the broader western and all-German institutions. The contours of such change are only dimly apparent at present. Whether the pressure for change will result in institutional reinvigoration or institutional decline for German social partnership remains to be played out in political processes of conflict and negotiation.

\section{THE STRIKE OF 1993}

The first great watershed for German social partnership in the postunification era came in the spring of 1993, when employers in the metal industries of eastern Germany unilaterally imposed a pay raise smaller than 
the one they had contractually agreed to pay. IG Metall responded by calling eastern workers out on strike in a high-stakes effort to beat back the employer offensive and demonstrate its influence in the new states of Germany. The ensuing conflict was to have major consequences for the future of industrial relations in eastern Germany. ${ }^{1}$

\section{Background}

In March r991, Gesamtmetall (the metal industries employers' association) and IG Metall signed similar three-year contracts for each region of eastern Germany, establishing basic pay levels and terms of employment for blue-and white-collar workers in the metal industries, including automobile assembly and parts, machinery, steel, shipbuilding, and electronics. These contracts provided for the phasing in of nominal wage parity with western workers over a three-year period, from 65 percent on April I, I99I, to I00 percent on April I, I $994 .{ }^{2}$ Widely praised at the time, this arrangement gave eastern workers hope for the future (and a reason not to move to the already crowded western labor market), social stability in a precarious economic situation, and an incentive for employers and investors to get in early while wage costs remained low.

The cosy relationships of I991, however, had evaporated by 1992 in the face of economic collapse in eastern Germany. Although the wage raise of April I, I992, was paid on schedule, many employers, especially small-tomedium-sized ones, complained that the continuing phase-in of nominal wage parity would bring economic ruin. Gesamtmetall was worried about its membership density in the East, which was much lower than levels enjoyed in western Germany; many eastern firms were seeking to go it alone in hopes of working out better deals with their own threatened workforces (Silvia I993, 22; Wever 1995). ${ }^{3}$ Employer criticism focused increasingly on the 26 percent pay raise due on April I, 1993.

I. Although published work is cited where appropriate, most of the facts and analysis in this section are based on interviews as well as participant observation conducted in eastern Germany in the spring of 1993.

2. Although contracts offered eastern workers nominal wage parity in the foreseeable future, real wage parity remained an elusive and distant goal. This was true because vacation and holiday schedules and other benefits were to be phased in over a longer period, because eastern workers were often grouped in lower pay categories than similarly employed western workers, and because contractual minimums negotiated in the West were typically supplemented by firmlevel premiums unavailable in the East. In the metal industries, this meant that by April I, I993, when wage levels in the East were scheduled to reach 82 percent of levels in the West, real wages (all things considered) would reach only 56.5 percent (Bispinck I993a, 3 I 5, 326).

3. Precise membership data for employer associations, including meaningful density figures, is well-guarded. For a useful discussion of the dissatisfaction of eastern association members (in the employer associations as well as other interest organizations), see Wiesenthal, Ettl, and Bialas I992. 
The pressure that Gesamtmetall now felt from many eastern member firms dovetailed with similar pressure that had been growing in the West in the 1980 and early I990s (Silvia 1994). The Mittelstand (the vast mediumsized firm sector, which included many innovative companies using advanced technology and oriented toward export as well as domestic markets) had grown especially critical of Gesamtmetall (dominated by large firms such as Daimler-Benz and Siemens) and its bargaining agreements. Mittelstand firms claimed that regional agreements since 1984 , which included wage increases, workforce protections, and a shorter work week, were raising costs beyond what they could afford. Some had gone so far as to threaten to withdraw from Gesamtmetall if the bargaining system was not considerably decentratized and deregulated.

In this context, facing pressure from its own membership in both West and East, fearing membership losses in the West as well as a permanently smaller base in the East, Gesamtmetall seized an opportunity to play hardball in what looked like a sure-win situation in the winter and spring of r993. A hard-line view came to dominate within the employers' camp: with 40 percent real unemployment and massive job insecurity in the East, with no recent history of western-style collective bargaining and labor conflict, and with membership in IG Metall quite new for eastern workers, the chances for mass mobilization and a successful strike in the East looked slim. Here was the breakthrough opportunity that Gesamtmetall sought for reform of the collective bargaining system in unified Germany. If IG Metall could be forced to retreat or pushed into a losing conflict in circumstances favorable to employers, a precedent could be set for holding down labor costs, introducing greater flexibility for firm-level adjustments, and demonstrating a new aggresiveness and resolve on the part of Gesamtmetall in the service of member interests.

With these goals in mind, in November of 1992 Gesamtmetall called for a revision of the three-year contract. Under terms of the revision clause, either party to the agreement could open new negotiations after January r, 1993, in light of changing economic and social circumstances. After much public posturing, negotiations began in Saxony on January I 8, 1993. Employers demanded cancellation of the three-year contract and its Stufenplan (phased-in wage parity); a one-year contract that would raise wages 9 percent in eastern Germany on April I, instead of the scheduled 26 percent; and a new "opening clause" (Öfnungsklausel) to allow renegotiation at the firm level for employers unable to pay scheduled wage increases (Bispinck $1993 \mathrm{~b}, 47 \mathrm{I}-75$ ).

IG Metall rejected these demands and asked for evidence to show how many firms could not pay the scheduled increase. Refusing to provide such information, Gesamtmetall declared the negotiations at an impasse on January 25 and called for arbitration. At the same time, the employers made it 
dear they would not accept an arbitrated settlement that exceeded their proposed 9 percent pay raise revision for April $\mathbf{r} .^{4}$

On February I5, arbitration proceedings ended in Saxony without a formal recommendation. The chief arbitrator cited irreconcilable differences caused by inadequate industrial and monetary policies and an economic transformation that had completely overtaxed the capabilities of the bargaining parties. Similar, patterned outcomes occurred in bargaining and arbitration proceedings in the other eastern German bargaining districts. On February I8, the employers' association in Saxony announced the cancellation of the contract and demanded new negotiations with the union, based on the employer demand for a 9 percent raise, with downward adjustments possible under an opening clause. In the event that no new agreement was reached, the employers announced their intention to proceed unilaterally with a 9 percent raise on April $\mathrm{I}$.

IG Metall denounced the employer action as illegal and without precedent in the postwar period. Filing a formal complaint with the labor court (which was not scheduled to be heard until May I4), the union began to prepare for a strike (Bispinck $1993 \mathrm{~b}, 475-76$ ).

With no agreement in sight, Gesamtmetall associations in each of the eastern bargaining regions announced their intention to raise wages by 9 percent on April I; IG Metall announced warning strikes, marches, and demonstrations beginning that same day, to be upgraded to a full-fledged strike if no settlement was reached. ${ }^{5}$ Employers denounced IG Metall as intransigent and out of touch with a membership in desperate economic straits; the union accused the employers of breaking the postwar social contract and undermining the foundations of free collective bargaining. ${ }^{6}$ Employers, backed by the business press and the broader employer community (through the umbrella federation BDA), appeared unusually confident of victory. Eastern metalworking employees, for their part, obviously felt

4. Each party appointed three members of an arbitration panel; these six members then appointed a seventh neutral member and chair. Arbitration is generally nonbinding in German coilective bargaining, which means the results can be rejected by either party. In this case, an arbitrated agreement would have been binding only if five of the seven panel members had agreed on the settlement (Silvia I993, II).

s. Unlike common practice in the United States, where strikes tend to be all or nothing, German unions typically build up to a strike gradually. Warsing strikes can last anywhere from a few minutes to a full day or more and are intended to strengthen the union bargaining position by demonstrating strike readiness and solidarity. When warning strikes do occur, negotiations typically continue or resume, leading in most cases to a settlement prior to the onset of a fuil-blown strike.

6. For the employer perspective, see, for example, Handelsblatt, April 6, 1993, p. 3. For the union view, see Der Gewerkschafter, 4I, no. 3 (March 1993). For a debate between the two viewpoints just prior to the first warning strikes, see Tagesspiegel, March 23, 1993, p. 2 r. 
betrayed by the unilateral reduction of their scheduled pay increases; yet according to numerous journalistic accounts they also appeared wary about going out on strike in a period of massive layoffs and economic crisis. Union representatives spoke militantly in public of the need to defend collective bargaining and free trade unionism but more hesitantly in private of their uncertainty regarding the viability of a strike in eastern Germany. Press editorials called for reason on both sides, especially exhorting IG Metall to avoid leading its new eastern members into a labor-market disaster. In a front-page editorial cartoon, Handelsblatt, Germany's leading business daily, showed IG Metall president Franz Steinkuthler sitting at the helm of a small boat, steering his eastern members over the crest of a great waterfall. ${ }^{\text {? }}$ The Economist titled its article on the coming conflict "Mass Suicide." 8

\section{From Partnership to Open Conflict}

Highly successful warning strikes throughout the new German states on April I-z and again on April I4-I 5 shattered both employer expectations and western preconceptions of eastern worker passivity. Even Michael Fichter, for example, a leading Berlin-based observer of eastern German industrial relations since 1989 , had referred to "the widespread instance of lethargy and passive expectation.... after years of being watched ovet, taken care of, and having favors and social improvements-when forthcoming-doled out to them, East Germans seem to be particularly prone to such behavior" (Fichter 1991, 35)..$^{9}$ For Gesamtmetall, the comfortable illusion vanished that easterners, after sixty combined years of nazism and command communism, would no longer stand up for their own interests when forcefully challenged. For IG Metall, the demonstrative shattering of this same troubling preconception cast new light on the union's bargaining position in eastern Germany.

For a few days, an early settlement looked possible. Kurt Biedenkopf, prime minister of Saxony, offered his services as a mediator, leading to discussions between IG Metall and employers' association (VSME in Saxony) on April 4 and 5. An agreement was reached between the two sides, reinstating the scheduled April I pay raise but stretching out the timetable for full parity by one additional year. IG Metall headquarters in Frankfurt indicated its willingness to accept the compromise; Gesamtmetall headquarters in Cologne, however, turned it down, forcing the Saxon employers'

7. Handelsblatt, April 5, 1993, P. I.

8. The Economist, April 24,1993 , pp. $71-72$.

9. See also Mahnkopf I991, 276-79, and Röbenack and Hartung 1992. As Der Spiegel put it on the eve of the strike: "In the workplace, employees are profoundly insecure; fear of losing their jobs is paralyzing their willingness to strike” (Der Spiegel, no. 13 [1993]: r22; author's translation). 
association chairman to resign his position. IG Metall pointed to this failed effort at compromise as evidence that Gesamtmetall's hard-line position was unreasonable. ${ }^{10}$

Rumors of further behind-the-scenes discussions and possible compromise solutions circulated throughout the month of April and into May. Publicly, however, both sides hardened their positions. The first strike votes, held on April 26-28, were 85 percent in favor in Saxony and 90 percent in favor in Mecklenburg-Pomerania. A parallel vote in the eastern steel industry, also organized by IG Metall but negotiating separately, was 86 percent in favor (Bispinck 1993 b, 477).

The strike began in Saxony on May 3, with 7,000 workers at twenty workplaces, and in Mecklenburg-Pomerania on May 4, with 12,500 workers from twenty-four workplaces. The union raised the numbers gradually, so that by the second week, 30,000 workers from seventy-five workplaces had joined the strike. Solidarity among the strikers, who received an average of DM 220-50 (about $\$ 150$ ) per week in strike benefits from the union, appeared strong. ${ }^{11}$ There were no signs at all of what the employers had expected: an early return to work by dispirited eastern workers.

On May ro-r 2, IG Metall escalated the stakes by holding strike votes in the rest of eastern Germany, with 81 percent in favor in Berlin-Brandenburg, 86 percent in Saxony-Anhalt, and 85 percent in Thuringia (Bispinck $1993 \mathrm{~b}$, 477). On May I2, 400,000 workers and their supporters demonstrated throughout Germany in support of the strikers, including over 50,000 western workers who briefly laid down their tools in solidarity. ${ }^{12}$ On May I3, the IG Metall national executive board announced its decision to spread the strike to all of eastern Germany. By the end of the second week (May I4), 50,000 eastern metalworkers were on strike. ${ }^{13}$

Intensive negotiations resumed in Saxony, again with the mediation of Kurt Biedenkopf, finally yielding a settlement on May I4. The terms of this agreement served as a closely followed pattern for the other regions of eastern Germany and the eastern steel industry as well. The parties agreed to the principle of phased-in wage parity for eastern workers but established a new timetable. In a symbolic but important gesture for the union, the 26 percent raise was reinstated retroactively to April I. Effective April 16, the

ro. For an account of the early abortive settlement, see Der Spiegel, no. I9 (1993): $114-17$.

iI. See, for example, Andreas Ordag, "Metallerstreik in Ostdeutschland," Süddeutsche Zeitung, May 6, I993, p. 3.

12. Reported by IG Metall in its newsletter "Metall Nachrichten für den Bezirk Küste," May 13, $_{3} 993$.

13. Dagmar Deckstein, "Ein fast genialer Kompromiß," Süddeutsche Zeitung, May 15 , 1993, p. 4 . 
raise was dropped to 9 percent (plus anything else that individual firms had agreed to , then raised again in June, September, and December, so that the 26 percent level was reached by the end of the year. Further raises in 199496 were scheduled to bring wage parity between East and West by July I, 1996. The employers issued a statement conceding that the extraordinary contract cancellation, used in this case only, was not an appropriate solution to collective bargaining problems. ${ }^{14}$

The union thus secured its main demands: reinstatement of the 26 percent pay increase, an admission by the employers that the contract cancellation would set no precedent for future labor conflicts, and a defense of phased-in wage parity for eastern workers. In addition, the union resisted the introduction of an "opening clause." Most important, perhaps, the union discovered in its new eastern membership a highly mobilizable force capable of conflict, solidarity, and personal sacrifice.

Employers secured considerable total labor cost savings for the period 1993-96, during the lengthened phase-in of wage parity. ${ }^{15}$ In addition, Gesamtmetall was able to demonstrate a new bargaining aggressiveness on behalf of its members, as well as provide support services during a strike, to help convince skeptical eastern employers to join or retain membership in the association. But the employers, in the end, were forced to give in to the central union demands, including the concept of phased-in eastern wage parity; and they were forced to back down in the face of unexpectedly determined employee militance.

Instead of an opening clause, Gesamtmetall settled for a new "hardship clause." While both allow for downward wage adjustment at designated firms, the distinction is critical. An opening clause would put the essential power in the hand of firms and their works councils to negotiate lower wage levels. In a period of economic crisis and mass unemployment, works councils would find themselves under great pressure to make substantial concessions. A hardship clause, on the other hand, puts the essential power of approval in the hands of a union-employer commission, giving IG Metall effective veto power. While the employers heralded this as a breakthrough in the direction of greater wage flexibility, the union vowed to use the new instrument selectively, to monitor and control carefully all temporary adjustments.

14. As reported in IDS News: "Under the settlement, the employers recognised that breaching the original agreement was an 'unavoidable emergency measure solely occasioned by the unique situation in the five new Länder. . . Terminating collective agreements is not an appropriate means for resolving collective disputes" " (IDS European Report, no. 378, June 1993, P. 5).

15. The amount has been estimated to be as high as DM 6 bitlion (Silvia 1993, 13; Suddeutsche Zeitung, May 2x, 1993, p. I). 
Striking workers clearly viewed the settlement as a victory. With only 25 percent required for ratification, votes in favor totaled 78 percent in Saxony; 6I percent in Mecklenburg-Pomerania, Thuringia, and Saxony-Anhalt; 46 percent in Berlin-Brandenburg; and 78 percent for the eastern steel industry. ${ }^{16}$

\section{Explaining the Unexpected}

Where did the eastern workers find such unexpected resolve? Why did they choose to go out on strike in large numbers in a high-risk situation? Their interest in higher pay was clearly an important factor. Expectations had risen dramatically after unification; living costs had also risen rapidly toward western levels. Only wages had not. For similar work, easterners were paid far less than western workers, and the 26 percent raise scheduled for April I was seen as a major step toward parity. Wage interests alone, however, are not sufficient to explain the high-risk choice to strike. Union and worker bargaining power is typically low and the strike threat is least credible during periods of mass unemployment; at such times, worker militance is typically restrained, in spite of interests in higher pay (Katz and Kochan 1992).

There are, therefore, two other necessary parts to the explanation for eastern militance. Worker mobilization in this case was fueled by extraordinary passion, a product of the combined frustrations and disillusionment that German unification had produced for eastern Germans. ${ }^{17}$ In the rush to unification, easterners had been promised prosperity to go with their newfound freedoms. What they found instead was economic crisis, mass unemployment, rising costs, great job insecurity, and western employers and government officials taking over their land. For easterners in the metal industries, the unilateral employer cancellation of the scheduled pay raise was the last straw. The bitterness and rage of what was in some ways a colonized people (Knuth 1993; Baylis 1993, 87) was channeled into this strike, much to the benefit of IG Metall.

The final necessary condition to explain eastern mobilization, therefore,

16. The lower figure for the Berlin area reflects a market converging rapidly around West Berlin levels, with both higher living costs and greater pressure on employees to work at western standards. The last of the eastern regions to settle, Berlin-Brandenburg produced a strong union critique against the Saxon settiement, arguing for quicker wage parity in an area where social differences were most painfully visible (Bispinck 1993 b, 477; Siiddeutsche Zeitung, May 19, 1993, p. 2).

17. See, for example, Marc Fisher, "Many in East Germany Redirect Their Anger," International Herald Tribune, March 27-28, 1993, p. 6. See also the editorial "Politisches Warnsignal" in Suddeutsche Zeitung, May I 8, 1993, p. 4; "Wir stehen unter Druck," Der Spiegel, no. 17 (1993): 124-25; and Ferdinand Protzman, "Strike in Eastern Germany: Economics and Anger," New York Times, May 5, 1993, p. A3. 
was the existence of a framework of credible institutions into which the passion could be funneled with reasonable prospects of success. These institutions were largely imported from the West: codetermination based on elected works councillors who could, in their capacity as union members, provide strike leadership, and a system of comprehensive regional collective bargaining, which included the participation of a powerful, conflict-tested metalworkers' union. The presence of these proven institutions, and the reassuring words of IG Metall that strikes were appropriate, legal, and winnable, provided the structure necessary for easterners to channel their passion into appropriate action (as opposed to either passive disillusionment and withdrawal or inappropriate action such as attacks on foreigners or other scapegoats).

And most important, why did IG Metall and its eastern membership win? The employers were certainly confident of victory, and with good reason. The careful analyses of perceptive academics such as Birgit Mahnkopf (r991, I993) and Klaus Armingeon (I99I) pointed clearly toward declining union influence in unified Germany. If this were the case, it would hardly lead one to expect a major IG Metall victory in eastern Germany in 1993. The prevalent viewpoint, however, underestimated two important factors: the passion and potential militance of eastern workers, and the resilience and adaptability of the institutions of industrial relations in the Federal Republic, in particular codetermination and the system of regional collective bargaining.

Under adverse circumstances, IG Metall won this strike because (I) it made the strategic and rather risky decision to strike at a time when the most prudent course of action might have been some face-saving compromise; (2) eastern workers in large numbers made the courageous decision to risk future employment prospects for an issue in which they deeply believed (phased-in wage parity); and (3) western institutions of industrial relations, transplanted and adapted to conditions in the East, afforded a viable framework in which the strike could be fought and won. Codetermination law meant that most works councillors had received union training and could thus provide a union base in most plants; regional collective bargaining made it possible to mobilize widespread solidarity.

For other sectors of the eastern economy, the settlement in the metal industries set an important pattern. In interviews in eastern Germany in March and April of 1993, I heard time and again from representatives of non-metal sectors that they were waiting to see what happened in the metal industry conflict. Union representatives at OTV (the public sector) and DPG (postal and telecommunications workers), for example, said that if IG Metall lost the strike, their own bargaining partners (chiefly in the Federal Ministry of the Interior) could be expected to follow a similar hard-line, 
union-challenging strategy. For both of those unions, comprehensive collective bargaining contracts were set to expire within a few months of the metal conflict. The IG Metall victory, however, led to a soft-line government strategy and a peaceful settlement with ÖTV and DPG based on phased-in wage parity.

The conflict and settlement in the metal industries, in other words, were precedent-setting events that led to a widespread consolidation throughout the eastern economy of $(I)$ nominal wage parity for eastern workers in the medium term, and (2) new institutions of industrial relations, including considerable union influence along with comprehensive, region-and sectorbased collective bargaining.

Although the crisis of social partnership was far from over, this strike and its settlement greatly increased the prospects for continuing social partnerstyle relations between employers and unions in eastern Germany. ${ }^{18}$ It was still possible, however, that the union victory was a Pyrrhic one, a possibility that cannot be discounted. ${ }^{19}$ Much depends on economic and industrial development in eastern Germany as well as the outcome of future labor conflicts in both eastern and western Germany.

\section{CASE STUDIES IN THE METAL AND ELECTRONICS INDUSTRIES}

Evidence gathered from ten case studies in the metal and electronics industries in eastern Germany expands, updates, and largely confirms conclusions drawn from the strike of 1993.20

Case-study evidence shows first of all a wide range of plant-level diversity

r8. In a perceptive analysis, Horst Kern $\{1994,38-45$ ) argues that what IG Metall gained above all from the eastern strike was credibility: a demonstration of the capacity to mobilize its membership that would greatly strengthen the political and economic role of the unions in the new German states.

19. Note the long bistory in the United States and elsewhere of great labor victories followed by prolonged periods of union decline. I am indebted both to Nick Salvatore and Jonas Pontusson, each of whom separately impressed upon me this point.

20. Case-study presentations are based on plant visits, interviews, and documents collected between 1990 and 1995 . I first visited Hella in Meerane and VW-Chemnitz in 1994, the other eight firms at least three times each between 1990 and 1995 . I conducted in-depth interviews ranging in length from one to four hours with works councillors, managers, and union representatives. Some of the plant visits and interviews in Berlin and Rostock I conducted alone, others were conducted together with Larissa Klinzing of Humboldt University. For the cases in Saxony, Uitrich Jirgens of the Wissenschaftszentrum and I made research trips together to those plants in 1991, 1992, and again in 1994. Additional interviews were also conducted at several of the plants by research associates Owen Darbishire and Aline Hoffmann. Detailed presentations of the cases are presented in Turner forthcoming, chap. 3. The case studies were selected from a broader original sample, to demonstrate the full range of outcomes along a continuum from successful to failed adjustment (Jürgens, Klinzing, and Turner 1993). 
along a number of dimensions, including characteristics of the transformation, production organization, and industrial relations. For production organization, outcomes range from state-of-the-art lean production at Opel-Eisenach, to innovative group work at Knorr-Bremse (the former Berliner Bremsenwerk), to rather traditional ("extended assembly line") production at ABB Kraftwerke Berlin (the former Bergmann-Borsig). For industrial relations, outcomes range from plants with influential works councils backed up by strike-hardened, mobilizable workforces (Siemens in Rostock, VW in Mosel), to highly cooperative works councils whose workforces have as yet shown little interest in mobilization (Niles in Berlin, Opel in Eisenach), and from firms committed to the employers' association and comprehensive collective bargaining (VW in Mosel) to nonmember, weakly unionized firms (Hella in Meerane).

Although a similar range of diversity exists in western Germany, the diversity appears considerably more pronounced in the East. Cases that would be outliers in the West are less unusual in the East; it is, in fact, difficult to find a real mainstream in the new federal states. There are, nonetheless, observable patterns of economic development and industrial relations that can be clearly discerned in the case studies considered here.

\section{Findings: Partnership and Modernization}

The most important observation to emerge from the case studies is the following: in a very short period of time (five years), a solid base for long-term, stable relations of social partnership has developed in eastern Germany.

Employer associations, despite low membership density relative to the West and intensive internal debate regarding strategy, have established a base for future growth and negotiation. Almost all large, influential firms in the East are members, and the associations play the key role from the employer side in setting wage standards at both sector and regional levels. Most of the managers interviewed indicated that their firms were committed members of the appropriate association. Employer solidarity, they maintained, was especially important in the difficult circumstances of the East; they viewed comprehensive collective bargaining by strong employer associations as the best way to prevent cutthroat and self-defeating labor-market competition and to maintain the high standards, quality, and profits for which German industry in the West has been known. All managers interviewed, even at nonmember Hella, fully expected the associations to occupy the same prominent position in the East that they have occupied in recent decades in the West.

There also appeared to be a solid base for the continuing development of 
union influence in eastern Germany. At the case-study firms, union membership levels for the most part equaled or exceeded membership levels at comparable western firms. In some cases, membership density was considerably higher, as at the electronics firms Siemens and El Pro. The two lowdensity cases were Hella (a small firm, most of which are also low-density in the West) and Opel-Eisenach (a special case, at which unionization was nonetheless on the rise). In all of these cases except Hella, the works councils were dominated by members of IG Metall. At several of these companies, strike preparations (or the actual strike itself) had strengthened union influence among the workforce; even where this had not occurred (as at Niles and VW-Chemnitz), works councillors remained committed union members and promoted union membership among the rank and file. In almost every case, works councillors, unionists, and managers predicted future high rates of unionization at their firms.

These findings offer a quite different perspective when set against the many pessimistic speculations on the future of unions, employer associations, and social partnership in eastern Germany (Mahnkopf I99I; Armingeon 1991; Wiesenthal, Ettl, and Bialas 1992). In fact, the future does not look at all bad for unions and employer associations here, at least at the frm level. True, many small and medium-sized employers do not belong to the association and set their own pay levels. As the economy of the East improves and as firm earnings rise, however, there is little reason to think that these nonmember firms will forgo the considerable benefits of membership (including legal advice, strike support, market information, and business contacts). For employees, the strike of 1993 has ensured a strong base of union support among both rank and file and works councils in the metal and electronics industries.

Comprehensively organized collective bargaining remains the primary mechanism for wage setting in eastern Germany and shows no signs of losing this role. Since plant premiums are less in the economically backward East, regional contracts bear an even closer relation to actual pay and other standards than is typically the case in the West. Where employers undercut bargained wage levels (sometimes with works council consent), contractual standards remain the benchmark for downward adjustment as well as the stated goal of works councils for the coming years when the crisis passes and economic growth resumes.

Relations of social partnership are thus already strongly entrenched in negotiations between unions and employer associations. At the firm level, works councils are at least as likely (and in many cases more likely) than in the West to work cooperatively and flexibly with management in the interest of firm survival. Works councils at the case-study firms are highly unionized 
(and this is typical throughout the East among larger firms in the metal and electronics industries); the works council-union-management social partnership appears firmly established at the level of the individual employer.

A second critical finding apparent from the case studies is the existence in the mid-1990s of a strong base for the modernization of industry in eastern Germany. Innovations at eastern plants include group work; aspects of lean production, including just-in-time parts delivery; and the latest technology. In the fight for survival, works councils collaborate closely with management in the introduction of innovation; in many cases, the works councils have pushed management (the reverse of the more usual case) to invest in new methods and to remove or reeducate authoritarian-minded "old red socks" who stand in the way of modern, participatory relations. In eastern Germany, firms found greenfield and semi-greenfield opportunities to introduce innovations more easily than in the industrially established West. They also found skilled workforces eager to accept innovation in the drive to keep plants open and preserve jobs.

Whether the strong base for modernization in eastern Germany becomes the dominant economic reality there depends on many factors, ranging from world and European economic conditions, to German federal and regional economic policy, to the outcomes of future collective bargaining rounds. From the evidence presented here, however, a strong case can be made to support the predictions of eastern managers and works councillors that over the next ten to twenty years, the new federal states will become the most modern part of the German economy. The strong base for modernization developed in only five years offers evidence to contradict widely pessimistic predictions regarding economic development in eastern Germany (see, for example, Grabher 1992).

The third key finding from case-study evidence concerns the important role played in modernization and economic development by legacies of industrial and social organization from the former GDR. David Stark has shown how the inherited form of industrial organization begets contrasting, "path-dependent" processes of privatization in Poland, Czechoslovakia, Hungary, and eastern Germany (Stark 1992). Thus the Treuhand as a unique organizational form and approach to privatization has roots in the industrial structure (and concentration) of the GDR. In sirnilar fashion, the evidence considered here demonstrates a clear relationship between older shopfloor practices and the potential for particular kinds of modern production organization. Modern shopfloor teamwork in eastern Germany, where management is astute enough to develop it, builds at least indirectly on former traditions of collective work and improvisation. Such innovationsuitable traditions arise not so much from formal brigade structures as from 
tacit opposition to (and in spite of) former authoritarian practices. As a response to the inefficiency of a state-run economy, for example, groups of workers met their norms by improvisation and collective effort in the face of persistent material shortages and obsolete equipment (Voskamp and Wittke I991; Kern I991). Habits bred by years of common effort and adaptation in difficult circumstances provide fertile ground in the 1990 s for the introduction of modern group and teamwork. This potential is well illustrated by successful innovations in production organization at Knorr-Bremse, Opel-Eisenach, VW-Mosel, VW-Chemnitz, and Hella, among others.

"Old red socks" in management, on the other hand, are a human legacy that is more mixed in its blessing. Firms in the East have built on this legacy for want of a viable alternative. On the negative side, former communist managers need training in cost-benefit analysis, human resource management, and modern relations with employees. Works councillors at several firms complained about inherited authoritarian bosses and their inability to work in a spirit of cooperation and trust either with the works councils or with other employees. On the positive side, however, such individuals do have experience in leadership and organization, they often possess considerable shopfloor knowledge by virtue of past apprenticeships and other technical training and on-the-job experience, and most important, they are desperate to hang on to their jobs and thus will do just about anything top management asks. Where top management has related to the old red socks strategically, such individuals have been sifted through, the bad ones sorted out, and the remaining core retrained to work in a facilitating role (rather than a commanding one) for shopfloor and office teams. This takes a major effort on the part of management, but it can pay off, as for example at Knorr-Bremse, VW-Chemnitz, and Hella. In successful cases, retrained old red socks bring ( $\mathrm{I}$ ) a powerful desire to adapt; (2) technical and managerial skills; and (3) a past practice of collaboration with eastern shop and office employees. This is a legacy on which the best firms can build in the push toward modern work organization.

Another important legacy can be found in the employment and training companies (ETCs) that have been spun off from several of the case-study firms (Knuth I993; Jürgens, Klinzing, and Turner I993, 240-4I). In these cases, displaced employees using available plant space and surplus equipment are combined in a government-subsidized nonprofit company that provides jobs and training while performing necessary infrastructure tasks such as demolition and environmental cleanup. In the best cases, led by "unleashed" ambitious and entrepreneurial former skilled workers, these companies have in turn spun off small private firms that have survived to provide permanent jobs and even production innovations in the new market 
economy. The jury is still out on the ETCs, and whether the latter successful cases are more than isolated exceptions. At the very least, the ETCs have provided one-to-three more years of employment for displaced workers who then enter the ranks of the unemployed; at best, ETCs, especially when adequately funded (the main struggle for these bodies), have afforded bridges to future skills, employment, and even new firms and product or process innovation.

In addition to the above findings, each of which offers some grounds for an optimistic assessment of developments in the eastern economy, the evidence examined also shows major problems and potential obstacles on the road to a modern social-partnership economy. Employer associations, as we have seen, are undersubscribed; unions are losing membership, largely as a result of unemployment but also in some cases as a product of disillusionment; and works councils in many cases, although working closely with management and gaining some input, are weak in the capacity to mobilize the workforce and develop independent negotiating positions. Pessimistic analysts take each of these problems as indicators of the demise of employer associations, unions, and social partnership. An alternative interpretation, however, more in line with the evidence presented here, views such problems as indicators of transformation and institutional adaptation, quite possibly on the road to a modern economy regulated by strong social partners.

Other problems, however, may well prove more intractable and potentially destabilizing for social partnership in the East. For one thing, although this was not the case at any of the case-study firms, managers and works councillors told us repeatedly of other firms in the area that were paying at below contractual levels, with the agreement of their own works councils. In some cases, firms had dropped out of the employers' association (or never joined) in order to do this; in other cases, firms were doing this illegally in spite of association membership. In the latter cases, the union was reluctant to take legal action, since the better political solution lay in developing a union-conscious works council rather than fighting against an agreement to which elected works councillors had consented.

There is no doubt that this practice is currently widespread throughout eastern Germany (and has also become a problem in western Germany). Possible interpretations, however, vary. Does this phenomenon represent the beginning of the end for comprehensive collective bargaining led by strong employer associations and unions-the pessimistic and perhaps prevalent view? Or does this subcontractual wage-setting reflect a temporary adaptation and informal flexibility in a period of crisis and transformation? Considerable evidence supports the latter view: the continuing unionization of works councils that make such agreements; the consistent 
claim on the part both of works councils and management that such "adjustments" are only temporary, to save jobs in desperate circumstances; and the willingness of union and employer association to look the other way. Sources within IG Metall, in fact (off the record), view such firms as potential sites for future union mobilization, if and when employers betray the promise and attempt to make these "temporary" adjustments permanent.

The most serious problem for social partnership and modernization in eastern Germany is clearly deindustrialization, and the possibility that industry in the East will never recover from its dramatic collapse of $1991-92$. It is difficult to imagine strong unions and employer associations in the absence of a substantial industrial base. Deindustrialization, with its corresponding mass unemployment, has indeed been the primary source of union membership decline in eastern Germany since 1992. The cases we have looked at, on the other hand, show potentially successful and innovative firms that may well attract future investment and contribute to processes of industrial recovery. Much depends here on government economic policy, levels of public and private investment, and the capacity of the social partners to continue to negotiate compromise agreements that set the framework for stability and expansion.

A final problem, linked directly to the preceding one, is continuing and long-term mass unemployment. In every case study, people related wrenching stories of almost unbelievable downsizing and mass layoffs. The firms that survived sell-off by the Treuhand did so with a fraction of their previously employed workforce. It is no secret that many of the displaced have no hope of future employment. For older workers and for many women forced out of the workforce into early retirement or long-term unemployment, the injustice and trauma of dislocation are extreme. The instability of mass unemployment is thus a potentially dangerous cost of rising productivity in eastern Germany. Not only does mass unemployment result in heavy and long-term fiscal burdens on the welfare state, massive dislocation opens the door for demagogery and right-wing terrorism against foreign or domestic scapegoats. Mass unemployment, in other words, whether in the East or West, threatens the fabric of postwar German democratic stability.

Once again the question arises whether these problems pose a long-term danger or represent temporary outrageous behavior in a period of profound dislocation. The answer depends in part on the speed with which economic growth takes off in the East; to that extent, the evidence of modernization examined here offers grounds for hope. The answer also depends, however, on the ability of the social partners, and especially the unions, to channel frustration and protest in constructive directions. Here again, the strike of 
r993 gives us reason to take an optimistic perspective. The danger of social instability in unified Germany, however, should not be underestimated.

\section{SOCIAL PARTNERSHIP: RESILIENCE AND ADAPTATION IN EASTERN GERMANY}

Evidence from other sectors supports conclusions drawn from the metal and electronics industries: social partnership is alive and well in eastern Germany; employer associations and unions have established comprehensive collective bargaining coverage that looks likely to endure; both employer associations and unions appear to have solid bases for present and future membership; eastern Germany appears well poised for future economic growth and modernization in both manufacturing and services. ${ }^{21}$

Although membership density is lower for employer associations in the East than in the West, most large firms belong. The associations have established offices and a network of services, and have taken an aggressive stance in pursuit of broadly acceptable collective bargaining agreements. Union membership density, by contrast, is higher in most sectors in the East than in the West and appears likely to remain so. 22 Unions across a range of sectors have established solid membership bases that include most elected works and personnel council the public-sector equivalent of the works council) members, who have in turn been trained in codetermination rights by the unions. While the building of effective shop-steward-based, plantlevel union organization proceeds slowly, some progress has been made, especially at large plants. Successful labor conflicts and bargaining outcomes, above all in the metal industry, have helped to establish a workplace base for union influence.

While economic collapse, deindustrialization, and mass unemployment have taken an enormous economic and personal toll, there is important evidence of modernization. Innovations in many cases surpass standard practice in the West, including new technology (new machinery in the factories; the installation of a state-of-the-art fiber optic network for eastern

2 I. See also Soskice and Schettkat 1993 and Wever 1995 . For additional sector studies, see Silvia 1993 and Fichter $199 \mathrm{I}$ and 1993 . In addition to the case studies in metals and electronics, my associates and I also conducted interviews in 1993-94 in the chemical industry, the public sector, and postal services and telecommunications, which together reinforced findings from the pattern-setting metal industries. Particularly striking was the extent to which representatives on both sides of the labor-management divide in other sectors watched events in the metal industries, and especially the strike of 1993 , for indications of their own future bargaining prospects.

22. As of December 31, 1992, eastern members accounted for 30.8 percent of the total membership of the DGB unions at a time when eastern population and workforce were about 20 percent of the German total (Kittner 1994, 85-86). 
telecommunications); and innovative production organization (semiautonomous group work, just-in-time supplier relations). Sectoral evidence shows a potentially solid base for economic take-off in the East.

Although numerous small and medium-sized employers may be undercutting established bargaining standards, this is likely to be a temporary phenomenon in a very difficult period of adjustment, tolerated in the short run by both unions and employer associations. Collective bargaining coverage is well established throughout the eastern economy, setting standards that are widely followed or at the very least used as benchmarks. While employer association membership is lower in the East than in the West (and also appears set to remain so), most large firms and many medium-sized firms in eastern Germany belong to the associations and themselves engaged in ongoing recruiting efforts to expand membership. ${ }^{23}$

The most serious problem for modernization in eastern Germany is deindustrialization. The "industrial core" has dropped to a dangerously low level, beyond which the necessary networks and infrastructure for the expansion of modern industry may no longer be available. On the other hand, the skills base is substantial in eastern Germany, contributing to a steady rise in productivity. When viewed next to comparable areas such as Northern Ireland, where great effort has been expended to develop industry, "underlying productivity" has risen considerably more rapidly in eastern Germany (Hitchens, Wagner, and Birnie 1993). Given access to western capital, the transfer of an institututional framework from western Germany, and a solid human capital base in the East, the possibility is strong for rapid growth in spite of rising wages. ${ }^{24}$ Major sources of rising productivity include new work organization, retraining, increased intensity of work, and new plant and technology (Wagner, Hitchens, and Birnie r994). Although far from a foregone conclusion, there is still a very real possibility that the prediction of eastern managers and works councillors will come true: that the East will in time become the most modern part of Germany. ${ }^{2 s}$

23. Parallel to the sector-level evidence presented here, Razeen Sally and Douglas Webber (1994) present macro-level evidence on the Solidarity Pact negotiations of 1992-93, and Webber (1994) analyzes the policies of the Treuhand, both of which demonstrate a "resurgence of the Geman model," including an active political and economic role for unions and employer associations. See also Wever 1995 on the intensification of "negotiated adjustment" in eastern Germany.

24. At thirty-two case-study plants in eastern Germany, Hitchens, Wagnes, and Birnie $\{1993,79-82\}$ found that underlying productivity rose so percent in a one-year period, from June 1990 to June 1991 .

25. Kern ( 1994 ) argues that the unions are now in a position to play a major role in both eastern and western Germany in promoting industrial policy and the renewal of the German production model, as an important contribution toward future economic development in both East and West. 


\section{EXPLAINING RESILIENCE}

Three factors in particular stand out as most persuasive in explaining the consolidation and resilience of social partnership in eastern Germany. First, the transfer of institutions from West to East has provided an important framework or superstructure for social partnership in the East. Employer associations, industrial unions, comprehensive collective bargaining, elected works councils, and legally mandated codetermination have all been transferred from western to eastern Germany. In the absence of this institutional apparatus, it is difficult to imagine the rapid consolidation of cohesive and encompassing interest groups that could engage in meaningful bargaining relationships (and indeed no such consolidation has occurred in other eastern European countries where institutional transfer is not the case). Works councils, unions, employer associations, individual employers-all have used collective bargaining or codetermination channels to promote their interests and negotiate settlements.

Second, this institutional apparatus has taken root in the remnants of the old system; the institutions, in other words, have proven compatible with and adaptable to the existing historical legacy. The combination of inherited skills and a tradition of informal, common workplace effort (itself in part a response to dysfunctional authoritarian relations in the old system), for example, has provided a base both for modern production innovations such as teamwork and for works council and union solidarity and activism. In the new soil, however, the institutions have changed. In the common struggle for survival and the protection of remaining jobs, for example, works councils cooperate closely with management-more so than in the West-while at the same time pursuing close union-works council relations. Unions collaborate with employers in the building of new institutions, such as the widespread Employment and Training Companies at the firm level (Knuth 1993) and broader industrial policy efforts at the Land level (such as Atlas in Saxony; Kern 1994). The extent to which such innovations indicate long-lasting institutional recombination or change remains an open question.

Finally, within the framework set by institutional transfer and historical legacy, actors have made choices that have promoted social partnership. At the plant and firm level, employees and elected works councillors have decided overwhelmingly to join unions, and in many cases to give active support to union-led campaigns when called upon to do so. At the industry level, metal and electronics workers quite surprisingly chose to back a risky strike that consolidated the position of pattern-setting IG Metall in eastern Germany. Large employers, for their part, have chosen to belong to appropriate employer associations and to give their backing to comprehensive 
collective bargaining. At the same time, the militance of small and mediumsized employers, many of them not members of the associations, has pushed employer associations to take the offensive in collective bargaining. This latter choice (one among a menu of possibilities) has in turn resulted in ( $\mathrm{I}$ ) contractual adjustments and innovations, including the lengthening of the time period for phased-in wage parity, that made social partnership more affordable in the East; and (2) a solidaristic labor response that has considerably strengthened the position of unions in the East.

Social partnership, in other words, has established itself in eastern Germany because of appropriate institutions (transferred in from the West), the flexible adaptation of these institutions to existing historical legacies, and the choices that individuals and organizations have made to support, stretch, and work within these given channels. The evidence points to each of these as necessary conditions for the consolidation and resilience of social partnership in the East.

For proponents of social partnership, however, the story does not necessarily have a happy ending. As an important component of market regulation in the new Germany, social partnership now finds itself saddled with the imperative to solve enormous problems and meet high expectations. Widespread and at this point inevitable dissatisfaction in the East, which in 1993 IG Metall was able to channel into a winning strike effort, could just as easily in the future take shape as dissatisfaction with the accomplishments of unions and employer associations, and the framework agreements they have negotiated. If the major economic and social problems facing unified Germany are not solved by existing actors operating withing the given institutional framework, the expansion of social partnership to eastern Germany could be the beginning of its end.

Institutional expansion, certainly in the contemporary German case, requires institutional change in order to solve new problems. Such change can be a source of institutional reinvigoration-as, for example, dissatisfied eastern members, with higher percentages of white-collar employees and women, push for organizational reform within the unions. If, on the other hand, change and reinvigoration are resisted or fail, expansion can lead to organizational decline. Although the extension of modern relations of social partnership into eastern Germany is no longer in question, the future success of this mode of market regulation remains unknown. The institutions of social partnership will either find new life, reinvigoration, and reform in the new Germany or, overtaxed and unable to make the necessary changes, they will stagnate and decline. 


\section{REFERENCES}

Armingeon, Klaus. 1991. "Ende einer Erfolgsstory? Gewerkschaften und Arbeitsbeziehungen im Einingungsprozeß." Gegenwartskunde I: 29-42.

Baylis, Thomas A. I993. "Transforming the East German Economy: Shock without Therapy." In Huelshoff, Markovits, and Reich I993, 77-92.

Bispinck, Reinhard. I993a. "Collective Bargaining in East Germany: Between Economic Constraints and Political Regulations." Cambridge Journal of Economics 17: 309-31.

-.. I993b. "Der Tarifkonflikt um den Stufenplan in der ostdeutschen Metallindustrie." WSI Mitteilungen 46, no. 8: 469-8I.

Fichter, Michael. I991. "From Transmission Belt to Social Partnership? The Case of Organized Labor in Eastern Germany." German Politics and Society 23 (Summer): 2 I-39.

- I993. "A House Divided: A View of German Unification as It Has Affected Organised Labour." German Politics 2, no. 1: 21-39.

Grabher, Gernot. I992. "Eastern Conquista: The "Truncated Industrialization' of East European Regions by Large West European Corporations." In H. Ernste and V. Meier, eds., Regional Development: A Contemporary Response. London: Bellhaven.

Hall, Peter A. 1986. Governing the Economy: The Politics of State Intervention in Britain and France. New York: Oxford University Press.

Hitchens, D. M. W. N., K. Wagner, and J. E. Birnie. I993. East German Productivity and the Transition to the Market Economy. Aldershot: Avebury.

Huelshoff, Michael G., Andrei S. Markovits, and Simon Reich, eds. 1993. From Bundesrepublik to Deutschland: German Politics after Unification. Ann Arbor: University of Michigan Press.

Jürgens, Ulrich, Larissa Klinzing, and Lowell Turner. I993. "The Transformation of Industrial Relations in Eastern Germany." Industrial and Labor Relations Review 46, no. 2: 229-44.

Katz, Harry C., and Thomas A. Kochan. I992. An Introduction to Collec. tive Bargaining and Industrial Relations. New York: McGraw-Hill.

Kern, Horst. I99x. "Die Transformation der östlichen Industrien: Soziologische Reflexionen uber die Ex-DDR." Die Neue Gesellschaft: Frankfurter Hefte 38: 2, I I 4-2I.

-. 1994. "Intelligente Regulierung: Gewerkschaftliche Beiträge in Ost und West zur Erneuerung des deutschen Produktionsmodells." Soziale Welt 45, no. I: 33-59.

Kittner, Michael, ed. I991. Gewerkschaftsjabrbuch I991. Cologne: BundVerlag. 
-, ed. 1994. Gewerkschaften Heute: Jahrbuch für Arbeitnehmerfragen, I994. Köln: Bund-Verlag.

Knuth, Matthias. r993. "Employment and Training Companies: Bridging Unemployment in the East German Crash." Paper prepared for the Conference of the Society for the Advancement of Socio-Economics, New York, March 26-28.

Mahnkopf, Birgit. 1991. "Vorwärts in die Vergangenheit? Pessimistische Spekulationen über die Zukunft der Gewerkschaften in der neuen Bundesrepublik." In Westphal et al. I991, 269-94.

- r993. "The Impact of Unification on the German System of Industrial Relations." Discussion Paper FS I 93-I02, Wissenschaftszentrum Berlin für Sozialforschung.

Markovits, Andrei S. 1986. The Politics of the West German Trade Unions. Cambridge: Cambridge University Press.

Polanyi, Karl. 1957. The Great Transformation: The Political and Economic Origins of Our Time. Boston: Beacon Press.

Röbenack, Silke, and Gabriella Hartung. I992. "Strukturwandel industrieller Beziehungen in Ostdeutschen Industriebetrieben.” Monograph $\mathrm{AG}_{3} / 3$, for the Commission for Research in Social and Political Transformation in the New States, Berlin.

Sally, Razeen, and Douglas Webber. I994. "The German Solidarity Pact: A Case Study in the Politics of the Unified Germany." German Politics 3, no. I: I 8-46.

Silvia, Stephen J. I993. " 'Holding the Shop Together': OId and New Challenges to the German System of Industrial Relations in the mid r990s." Berliner Arbeitshefte und Berichte zur sozialwissenschaftlichen Forschung, no. 83, Freie Universität Berlin, Zentralinstitut für sozialwissenschaftliche Forschung.

—. 1994. "A House Divided: Employers and the Challenge to Pattern Bargaining in a United Germany." Unpublished manuscript, American University.

Soskice, David, and Ronald Schettkat. 1993. "West German Labor Market Institutions and East German Transformation." In Ulman, Eichengreen, and Dickens I993, 102-27.

Stark, David. I992. "Path Dependency and Privatization Strategies in East-Central Europe." East European Politics and Societies 6, no. I: I7-54.

- 1994. "Recombinant Property in Eastern European Capitalism." Unpublished manuscript, Cornell University, Ithaca, N.Y.

Streeck, Wolfgang. x99r. "More Uncertainties: German Unions Facing 1992." Industrial Relations 30, no. 3: 317-49. 